\title{
Index to the First Five Years (1993-1997) of the Journal of Northeast Texas Archaeology
}

Timothy K. Perttula

Heritage Research Center, Stephen F. Austin State University

Follow this and additional works at: https://scholarworks.sfasu.edu/ita

Part of the American Material Culture Commons, Archaeological Anthropology Commons, Environmental Studies Commons, Other American Studies Commons, Other Arts and Humanities Commons, Other History of Art, Architecture, and Archaeology Commons, and the United States History Commons

Tell us how this article helped you.

This Article is brought to you for free and open access by the Center for Regional Heritage Research at SFA ScholarWorks. It has been accepted for inclusion in Index of Texas Archaeology: Open Access Gray Literature from the Lone Star State by an authorized editor of SFA ScholarWorks. For more information, please contact cdsscholarworks@sfasu.edu. 


\section{Index to the First Five Years (1993-1997) of the Journal of Northeast Texas}

Archaeology

\section{Creative Commons License}

\section{(c) (1) (8)}

This work is licensed under a Creative Commons Attribution-NonCommercial 4.0 International License 


\section{Index to the First Five Years (1993-1997) of the Journal of Northeast Texas Archaeology}

\section{Timothy K. Perttula}

With considerable help and assistance along the way, the Friends of Northeast Texas Archaeology have been able to successfully publish over the last five years (1993-1997) a journal of archaeological research concerning the prehistory and history of Northeast Texas. During 1993, the publication was entitled Notes on Northeast Texas Archaeology, as our intention was simply to publish an occasional joumal of papers and book reviews. When it became apparent (in part through the efforts of the East Texas Archeological Conference, which also began in 1993) that there were many worthy papers on Northeast Texas archaeology that warranted publication, the title of our publication was changed to the Journal of Northeast Texas Archaeology. The journal has been issued twice a year by the Friends of Northeast Texas Archaeology.

For those interested in the archaeology of Northeast Texas, this paper provides an index of articles, panel discussions, book reviews, and East Texas Archeological Conference abstracts published in the first 10 volumes of our journal.

$$
\begin{gathered}
\text { Abbreviations used in the Index } \\
\text { NNTA= Notes on Northeast Texas Archaeology } \\
\text { JNTA= Journal of Northeast Texas Archaeology }
\end{gathered}
$$

\section{ARTICLES}

Avery, George

1996 Eighteenth Century Spanish, French, and Caddoan Interaction as seen from Los Adaes. JNTA 7, pp. 27-68.

Blaine, Jay C.

1993 Problems in the Preservation and Study of Archaeological Metals in East Texas. NNTA 1, pp. 10-12.

Blake, Leonard

1994 Analysis of Rowland Clark Site Corn. JNTA 4, pp. 43-49.

Brown, Kenneth $M$.

1993 Four Clovis Points from San Augustine County, Texas. NNTA 2, pp. 26-49.

Carter, Mary Cecile

1995 Archaeology, The Caddo Indian Tribe, and the Native American Graves Protection and Repatriation Act. JNTA 5, pp. 4-8.

Cliff, Maynard B.

1997 The Middle Caddoan Period in the Lower Sulphur River Area. JNTA 9, pp. 9-16.

1997 Addendum to "The Middle Caddoan Period in the Lower Sulphur River Area." JNTA 10, p. 58. 
Corbin, James E.

1993 Vulnerability of Archaeological Sites in East Texas. NNTA 1, p. 9.

1996 Spanish-Caddoan Interaction in Eastern Texas. JNTA 7, pp. 20-26.

Derrick, Sharon McCormick

1997 A Study in Frustration: Analysis of Human Remains Removed from the Coker Mound Site (4lCS1). JNTA 9, pp. 21-29.

Dockall, Helen Danzeiser

1994 Human Skeletal Remains from the Tyson Site (41SY92). JNTA 3, pp. 37-50.

Foster, Eugene R., Jr. and Wayne Glander

1993 Data Recovery Efforts at the Millville Mill Site (41RK223), Rusk County, Texas. NNTA 2, pp. 76-80.

Gilmore, Kathleen

1996 Early European-Indian Ceremonies on the Red River. JNTA 7, pp. 1-2.

Hubbard, Velicia R.

1996 First Report on the Lake Sam Rayburn Archaeological Sites Inventory and Monitoring Project. JNTA 7, pp. 3-8.

Jones, Mary Cay

1993 Alley's Mill: A 19th Century Mill Town. NNTA 1, pp. 15-19.

King, Kevin and Mike Turner

1993 The West Island Site (41MX65). NNTA 1, pp. 25-33.

Loveland, Carol J.

1994 Rowland Clark and Dan Holdeman Site Human Skeletal Remains. JNTA 4, pp. 50 60 .

McCrocklin, Claude

1993 Chipped Glass, Ceramics, and Axe Handles. NNTA 2, pp. 8-13.

McGregor, Dan E.

1993 Artifact Repatriation and Collection Documentation. NNTA 1, pp. 13-14.

Middlebrook, Tom

1994 An Update of Archaeological lnvestigations at the Tyson Site (41SY92). JNTA 3, pp. 1-36.

1997 The Caddoan Occupation of the Attoyac and Angelina River Basins in the Middle Caddoan Period. JNTA 10, pp. 36-40.

1997 Notes on Caddoan Vessels Collected from the Mosquito Island Site (41AG66), Lake Sam Rayburn. JNTA 10, pp. 59-63.

Middlebrook, Tom and Timothy K. Perttula

1997 The Middle Caddoan Period in Fast Texas: A Summary of the Findings of the East Texas Caddoan Research Group. JNTA 9, pp. 1-8. 
Nelson, Bo and 'limothy K. Perttula

1993 The Z.V. Davis-McPeek Site, an Early Caddoan Mound Site in the Little Cypress Creek Valley, Upshur County, 'l'exas. NN'I'A 2, pp. 50-65.

Nelson, Bo and Mike ' lurner

1997 Middle Caddoan Sites in the Cypress Creek Drainage Basin. JNTA 10, pp. 1-11.

Perino, Gregory

1994 Archaeological Research at the Rowland Clark Site (41RR77), Red River County, Texas. JNTA 4, pp. 3-42.

1995 The Dan Holdeman Site (41RR 11), Red River County, Texas. JNTA 6, pp. 3-65.

Perttula, Timothy $\mathrm{K}$.

1993 The Problem of Site Looting in East Texas. NNTA 1, pp. 2-4.

1993 Means of Site Preservation in East Texas. NNT'A 1, pp. 5-8.

199.3 Archaeological Investigations at the Robert Potter and Harriet Ames Cabin (41MR51) on Potter's Point, Caddo Lake. NNTA 2, pp. 14-25.

1994 Editor's Introduction to “The Rowland Clark (4I RR77) Site." JNTA 4, pp. 1-2.

1995 Caddoan Archacological Investigations at the Dan Holdeman Site (41RR11) in Red River County, Texas: Editor's Introduction. JNTA 6, pp. 1-2.

1995 A Reconsideration of the Chronological and Cultural Placement of the Mortuary Remains and Grave Goods from the Dan Holdeman Site. JNTA 6, pp. 67-87.

1997 Middle Caddoan Period Archaeology in the Upper Sulphur River Basin. JNTA 10, pp. 41-46.

1997 The Archaeology of the Middle Caddoan Period in the Middle Red River Valley of Northeast Texas. JNTA 10, pp. 47-51.

1997 Index to the First Five Years (1993-1997) of the Journal of Northeast Texas Archaeology. JNTA 10, pp. 64-68.

Perttula, Timothy K. and J. Brett Cruse

1997 The Caddoan Archaeology of the Sabine River Basin during the Middle Caddoan Period. JNIA 9, pp. 30-37.

Perttula, 'limothy $\mathrm{K}$. and Bo Nelson

1997 41HS574, The Coleman Farm Site on Starkey Creek. JNTA 10, pp. 52-57.

1997 Construction Damages a Prehistoric Caddo Indian Archaeological Site at the City of Gilmer's proposed Lake Gilmer, Upshur County, Texas. JNTA 10, pp. 69-74.

Perttula, 'limothy K., Emest R. Martin, and Bo Nelson

1996 Caddo Ceramics on the Red River in North Central Texas. JNTA 8, pp. 51-57.

Perttula, Timothy K., Bob D. Skiles, and Bonnie C. Yates

1993 The Carlisle Site (41WD46), a Middle Caddoan Occupation on the Sabine River, Wood County, Texas. NNTA 1, pp. 34-62. 
Perttula, limothy K., Mike l'urner, and Bo Nelson

1997 A Radiocarbon Date from the Coker Mound (41CSI). JNTA 9, pp. 17-20.

Reese-Taylor, Kathryn

1995 Evidence of Resource Procurement and Manufacturing Techniques in Caddoan Ceramic Assemblages from the Sabine, Cypress, and Sulphur River Drainage Basins, Rusk and Titus Counties, Texas. JNTA 5, pp. 9-27.

Sichambach, Frank $\mathrm{F}$.

1993 A Summary of the History of the Caddo People. NNTA 2, pp. 1-7.

1997 The Development of the Burial Mound Tradition in the Caddo Area. JNTA 9, pp. $53-72$.

Schroeder, Eric A.

1997 Limited Testing at the Turbeville Site (41WD382), Wood County, Texas. JNTA 9 , pp. 42-52.

Speir, I Thomas E.

1993 Possible Archaeological Sites within the City Limits of Jefferson, Texas. NNTA I, pp. 20-24.

1996 Civil War Era Sites in East 'lexas: An Initial Inventory and Site Models. JNIA 7, pp. 9-19.

Speir, Thomas E. and David H. Jurney

1996 Archaeological Investigations at the Marshall Powder Mill (41HS17), Confederate States of America 1863-1865, Harrison County, Texas: 1994 Season. JNTA 8, pp. 1-49.

Turner, Mike

1993 A Two-Phase or Tiered Caddo Mound at the Camp Joy Site (41UR 144), Lake O' the Pines. NN'TA 2, pp. 66-75.

Turner, Robert L.

1997 Observations on Four Probable Middle Caddo Cemeteries in Camp and Upshur Countics. JNTA 10, pp. 12-35.

Walters, Mark

1997 The Langford Site (41SM 197), Smith County, Texas. JNTA 9, pp. 38-41.

Wilson, Diane

1995 Dental Paleopathologies in the Sanders Site (41LR2) Population from Lamar County, Texas. JNTA 5, pp. 29-59. 


\section{PANEL DISCUSSIONS}

Diminishing Caddoan Resources in East Texas. NNTA 1, pp. 1-14.

“Two Worlds Meet: The Caddoan People and Missions." JNTA 7, pp. 20, 69-85.

\section{BOOK REVIEWS}

Review of "Exploring Ancient Native America: An Archaeological Guide" (David Hurst Thomas), by Timothy K. Perttula. JNTA 9, pp. 73-74.

\section{ABSTRACTS OF THE EAST TEXAS ARCHEOLOGICAL CONFERENCE}

Abstracts from the 3rd East Texas Archeological Conference (1995). JNTA 5, pp. 61-65.

Abstracts from the 4th East Texas Archeological Conference. JNTA 7, pp. 92-95. 